\title{
Pelaksanaan Hak Mengajukan Rancangan Peraturan Daerah dan Hak Imunitas Anggota Dewan Perwakilan Rakyat Daerah
}

\author{
Mhd. Ansori ${ }^{1}$ \\ Fakultas Hukum Universitas Batanghari Jambi, Indonesia
}

\begin{abstract}
Abstrak. Ada beberapa pendapat mengenai fungsi DPRD, menurut Jimly Asshiddiqie "fungsi legislasi atau pengaturan dalam bentuk konkretnya terwujud dalam fungsi pembentukan peraturan yang mengikat warga negara" dan Bagir Manan menyebutkan "fungsi anggaran yaitu hak untuk turut serta menetapkan anggaran belanja tahunan daerah". Pada prakteknya dalam membentuk peraturan perundang-undangan termasuk didalamnya adalah menyusun dan membentuk peraturan daerah, DPRD seringkali mengalami kesulitan dalam memunculkan inisiatif penyusunan Peraturan Daerah yang akan menjadi kebijakan dalam penyelenggaraan pemerintahan dan pembangunan. Menurut Bagir Manan dalam bukunya menjelaskan hak imunitas yaitu hak kekebalan seorang anggota Dewan Perwakilan Rakyat dari proses hukum tertentu, kecuali imunitas tersebut tanggal atau ditanggalkan. Untuk menganalisis bagaimana penerapan konsep pelaksanaan hak mengajukan rancangan peraturan daerah dan hak imunitas anggota Dewan Perwakilan Rakyat Daerah di Indonesia. tipe penelitian yang digunakan adalah penelitian yuridis normatif, yakni penelitian yang difokuskan untuk mengkaji penerapan kaidah-kaidah atau norma-norma dalam hukum positif. Penelitian ini menggunakan "pendekatan konseptual, pendekatan perundang-undangan, dan pendekatan sejarah".
\end{abstract}

Kata Kunci: Peraturan Daerah, Imunitas, Dewan Perwakilan Rakyat Daerah

\begin{abstract}
There are several opinions regarding the function of the Regional People Representative Assembly, according to Jimly Asshiddiqie "the function of legislation or regulation in its concrete form is manifested in the function of forming regulations that bind citizens" and Bagir Manan said "the budget function is the right to participate in setting regional annual budgets". In practice, in formulating legislation including the formulation and formulation of regional regulations, Regional People Representative Assembly often has difficulties in generating initiatives to draft Regional Regulations that will become a policy in the administration of government and development. According to Bagir Manan in his book explaining the right of immunity namely the immunity rights of a member of the House of Representatives from certain legal processes, unless the immunity is dated or abandoned. To analyze how the application of the concept of the implementation of rights proposes a draft regional regulation and immunity rights for members of the Regional Representatives Council in Indonesia. the type of research used is normative juridical research, namely research focused on examining the application of rules or norms in positive law. This research uses "conceptual approaches, legislative approaches, and historical approaches".
\end{abstract}

Keyword: Local Regulation, Immunity, Regional People Representative Assembly

\section{PENDAHULUAN}

Secara materil, UUD 1945 telah memberikan nilai dasar dan kaidah yang fundamental yang dapat menjadi sistem ketatanegaraan Indonesia sekaligus sebagai cita hukum yang mempunyai fungsi sebagai alat untuk menguji hukum positif yang berlaku, alat untuk mengarahkan hukum positif menuju sesuatu yang adil dan benar, alat untuk menguji hukum positif dan rechtsidee konstitusi, tolak ukur bagi suatu hukum yang ideal, norma fundamental bagi pembentukan hukum. ${ }^{2}$ Pasal 18 Undang-Undang Dasar Negara Republik Indonesia Tahun 1945 menyatakan bahwa Republik Indoneia adalah negara kesatuan yang menganut Desentralisasi, yang merupakan dasar hukum penyelenggaraan pemerintahan daerah.

Dalam penyelenggaraan pemerintahan daerah kini berdasarkan Undang-Undang Nomor 23 Tahun 2014 Tentang Pemerintahan Daerah bahwa Pemerintahan daerah adalah penyelenggaraan urusan pemerintahan oleh Pemerintah Daerah dan Dewan Perwakilan Rakyat Daerah menurut asas otonomi dan tugas pembantuan dengan prinsip otonomi seluas-luasnya dalam sistem dan prinsip Negara Kesatuan Republik Indonesia sebagaimana dimaksud dalam Undang-Undang Dasar Negara Republik Indonesia Tahun 1945 dan menyatakan bahwa Dewan Perwakilan Rakyat Daerah adalah lembaga perwakilan rakyat daerah yang berkedudukan sebagai unsur penyelenggara pemerintahan daerah.

\footnotetext{
${ }^{1}$ Mhd.Ansori, Dosen Fakultas Hukum Universitas Batanghari

${ }^{2}$ Lihat La Ode Husen, Hubungan Fungsi Pengawasan DPR dengan BPK dalam Sistem Ketatanegaraan Indonesia, CV. Utomo, Bandung, 2005, hal. 19.
} 
Dewan Perwakilan Rakyat Daerah yang selanjutnya disebut DPRD sebagai lembaga perwakilan rakyat di Daerah merupakan wahana untuk melaksanakan demokrasi, sebagai Badan Legislatif Daerah berkedudukan sejajar dan menjadi mitra dari Pemerintah Daerah. Alat kelengkapan DPRD terdiri atas pimpinan, komisi-komisi, dan panitia-panitia. ${ }^{3}$

Menurut teori, fungsi pokok badan legislatif daerah ialah "menentukan policy (kebijakan) dan membuat peraturan daerah, menentukan anggaran pendapatan dan belanja daerah yang tercakup dalam hak budget, mengontrol badan eksekutif (pemerintah daerah) melalui hak-hak DPRD". 4

Ada beberapa pendapat mengenai fungsi DPRD, menurut Jimly Asshiddiqie "fungsi legislasi atau pengaturan dalam bentuk konkretnya terwujud dalam fungsi pembentukan peraturan yang mengikat warga negara"5 dan Bagir Manan menyebutkan "fungsi anggaran yaitu hak untuk turut serta menetapkan anggaran belanja tahunan daerah". 6

Pada prakteknya dalam membentuk peraturan perundang-undangan termasuk didalamnya adalah menyusun dan membentuk peraturan daerah, DPRD seringkali mengalami kesulitan dalam memunculkan inisiatif penyusunan Peraturan Daerah yang akan menjadi kebijakan dalam penyelenggaraan pemerintahan dan pembangunan. ${ }^{7}$

Menurut Bagir Manan dalam bukunya menjelaskan hak imunitas yaitu hak kekebalan seorang anggota Dewan Perwakilan Rakyat dari proses hukum tertentu, kecuali imunitas tersebut tanggal atau ditanggalkan. ${ }^{8}$ Akan tetapi masyarakat dapat mengetahui bahwa Hak Imunitas merupakan suatu hak yang tidak membuat kebal anggota Dewan Perwakilan Rakyat didalam bukunya Natabaya menyebutkan "padahal bahwasannya seorang Dewan Perwakilan Rakyat merupakan seseorang yang mewakili masyarakat luas yang memiliki interaksi sosial yang berstruktur disuatu kerangkan nilai yang relevan". ${ }^{9}$ Pada prinsipnya hak imunitas yang melekat pada DPR ataupun DPRD menimbulkan pro dan kontra. Ada yang menganggap bahwa perlakuan berbeda terhadap anggota DPRD dianggap sudah tepat karena pejabat negara berbeda dengan warga negara biasa. Ada juga yang beranggapan bahwa hal itu tidak wajar karena setiap warga negara mempunyai kedudukan sama di hadapan hukum. Pembedaan tersebut jelas bertabrakan dengan asas equality before the law. ${ }^{10}$

Berdasarkan uraian tulisan diatas maka penulis merumuskan masalah terbatas pada "Bagaimana pelaksanaan hak mengajukan rancangan peraturan daerah dan hak imunitas anggota Dewan Perwakilan Rakyat Daerah di Indonesia?"

Dengan tujuan untuk menganalisis bagaimana penerapan konsep pelaksanaan hak mengajukan rancangan peraturan daerah dan hak imunitas anggota Dewan Perwakilan Rakyat Daerah di Indonesia.

Pemerintahan dapat diartikan sebagai keseluruhan lingkungan jabatan dalam suatu organisasi. Dalam organisasi negara, pemerintahan sebagai lingkungan jabatan adalah alat-alat kelengkapan negara seperti jabatan eksekutif, jabatan legislatif, jabatan yudikatif, dan jabatan suprastruktur lainnya. Jabatan-jabatan ini menunjukkan lingkungan kerja tetap yang berisi wewenang tertentu dalam memberikan kekuasaan untuk melakukan atau tidak melakukan sesuatu. Karena itu, jabatan eksekutif, jabatan legislatif, jabatan yudikatif, dan jabatan-jabatan lainnya sering juga disebut kekuasaan eksekutif, kekuasaan legislatif, dan kekuasaan

${ }^{3}$ Deddy Supriady Bratakusumah dan Dadang Solihin, Otonomi Penyelenggaraan Pemerintahan Daerah, Gramedia Pustaka Utama, 2002, hal. 14.

${ }^{4}$ B.N.Marbun, "Perwakilan Politik Lokal dan Eksistensi DPRD dalam Konteks Otonomi Daerah" dalam Pasang Surut Otonomi Daerah, Cet. 1., Editor Anhar Gonggong, Institute for Local Development, Jakarta, 2005, hal. 410.

${ }^{5}$ Jimly Asshiddiqie, Pengantar Ilmu Jukum Tata Negara, Rajawali Pers, Jakarta, 2009, hal. 299.

${ }^{6}$ Bagir Manan, DPR, DPD, dan MPR dalam UUD 1945 BARU, UII Press, Yogyakarta, 2005, hal. 37.

${ }^{7}$ Mutiq H.N, "Pelaksanaan Fungsi Legislasi DPRD dalam Pembentukan Peraturan Daerah di Kabupaten Nunukan, Tesis, Magister Administrasi Publik Universitas Terbuka, 2018, hal. 3

${ }^{8}$ Bagir Manan, Op.Cit., hal. 45.

${ }^{9}$ H.A.S. Natabaya, 2004, Menjaga Denyut Konstitusi, Refleksi Satu Tahun Mahkamah

Konstitusi, Jakarta, Konstitusi Press, hal. 60.

${ }^{10}$ Jorawati Simarmata, Menafsirkan Hak Imunitas Anggota Dewan Perwakilan Rakyat Daerah (Analisis Surat Kemendagri Nomor 331/9914/Otda Tertanggal 14 Desember 2016) Jurnal Legislasi Indonesia Vol. 15 No. 01 - Maret 2018 : 01 - 10 , hal.2 
yudikatif. Pemerintahan yang dikemukakan di atas dapat disebut sebagai pemerintahan dalam arti umum atau arti luas (government in the broad sense). ${ }^{11}$

Dewan Perwakilan Rakyat Daerah sebagai lembaga legislatif di daerah termasuk unsur Pemerintahan Daerah turut serta merumuskan kebijakan dalam penyelenggaraan pemerintahan daerah, salah satunya diawali dengan merumuskan peraturan daerah. Berdasarkan Undang-Undang Nomor 23 Tahun 2014 tentang Pemerintahan Daerah, anggota DPRD mempunyai hak :

a. Mengajukan rancangan peraturan daerah;

b. Mengajukan pertanyaan;

c. Menyampaikan usul dan pendapat;

d. Memilih dan dipilih;

e. Membela diri;

f. Imunitas;

g. Mengikuti orientasi dan pendalaman tugas;

h. Protokoler;

i. Keuangan dan administratif.

Bruggink menyatakan, "bahwa aturan hukum yang dirumuskan dalam sebuah peraturan perundangundangan, menjadikan orang dengan kepastian dapat mengatakan bahwa ia ditetapakan oleh pengemban kewenangan hukum"12 dari pendapat Bruggink dapat disimpulkan "bahwa peraturan perundang-undangan adalah bagian dari aturan hukum dalam bentuk hukum tertulis, merupakan hukum positif'. ${ }^{13}$ Menurut Arsyad Somad, DPRD memiliki 4 (empat) kedudukan yaitu :

a. sebagai perwakilan rakyat.

b. sebagai legislatif daerah.

c. sebagai lembaga pengawas.

d. sebagai lembaga atau alat perpanjangan partai politik. ${ }^{14}$

Penjelasan Pasal 323 Undang-Undang Nomor 17 Tahun 2014 Tentang MPR,DPR,DPD dan DPRD:

Huruf a

Hak mengajukan rancangan peraturan daerah provinsi dimaksudkan untuk mendorong anggota DPRD provinsi dalam menyikapi serta menyalurkan dan menindaklanjuti aspirasi rakyat yang diwakilinya dalam bentuk pengajuan usul rancangan peraturan daerah provinsi.

Kelsen dalam teori jenjang norma hukumnya mengemukakan bahwa suatu norma hukum itu selalu berdasar dan bersumber pada norma hukum di atasnya, tetapi ke bawah norma hukum itu juga menjadi sumber dan menjadi dasar bagi norma hukum yang lebih rendah dari padanya. ${ }^{15}$ Terkait Hak Imunitas anggota DPRD, Pasal 338 Undang-Undang Nomor 17 Tahun 2014 Tentang MPR,DPR,DPD dan DPRD menerangkan:

(1) Anggota DPRD provinsi mempunyai hak imunitas.

(2) Anggota DPRD provinsi tidak dapat dituntut di depan pengadilan karena pernyataan, pertanyaan, dan/atau pendapat yang dikemukakannya baik secara lisan maupun tertulis di dalam rapat DPRD provinsi ataupun di luar rapat DPRD provinsi yang berkaitan dengan fungsi serta wewenang dan tugas DPRD provinsi.

(3) Anggota DPRD provinsi tidak dapat diganti antarwaktu karena pernyataan, pertanyaan, dan/atau pendapat yang dikemukakannya baik di dalam rapat DPRD provinsi maupun di luar rapat DPRD provinsi yang berkaitan dengan fungsi serta wewenang dan tugas DPRD provinsi.

(4) Ketentuan sebagaimana dimaksud pada ayat (1) tidak berlaku dalam hal anggota yang bersangkutan mengumumkan materi yang telah disepakati dalam rapat tertutup untuk

\footnotetext{
${ }^{11}$ Bagir Manan, Menyongsong Fajar Otonomi Daerah, Pusat Studi Hukum FakultasHukum UII, Yogyakarta, 2002, hal. 101.

${ }^{12}$ Bruggink dalam Sukamto Satoto, Op. Cit., hal. 2.

${ }^{13}$ Ibid, hal. 3 .

${ }^{14}$ Jorawati Simarmata, Op.Cit., hal . 3

${ }^{15}$ Mutiq H.N, Op.Cit., hal. 40
} 
dirahasiakan atau hal lain yang dimaksud dalam ketentuan mengenai rahasia negara sesuai dengan ketentuan peraturan perundang- undangan.

Menurut Bagir Manan dalam bukunya menjelaskan hak imunitas yaitu hak kekebalan seorang anggota Dewan Perwakilan Rakyat dari proses hukum tertentu, kecuali imunitas tersebut tanggal atau ditanggalkan. ${ }^{16}$ Akan tetapi masyarakat dapat mengetahui bahwa Hak Imunitas merupakan suatu hak yang tidak membuat kebal anggota Dewan Perwakilan Rakyat didalam bukunya Natabaya menyebutkan "padahal bahwasannya seorang Dewan Perwakilan Rakyat merupakan seseorang yang mewakili masyarakat luas yang memiliki interaksi sosial yang berstruktur disuatu kerangkan nilai yang relevan". ${ }^{17}$

Hak imunitas dalam hukum memiliki dua macam sifat, yaitu; yang pertama hak imunitas mutlak, merupakan hak imunitas yang tetap berlaku secara mutlak dalam arti tidak dapat dibatalkan oleh siapapun, yang tergolong hak imunitas ini, misalnya; pernyataan, pertanyaan dan atau pendapat yang dikemukakan di dalam atau diluar sidang atau rapat Dewan Perwakilan Rakyat. Yang kedua adalah hak imunitas kualifikasi, merupakan hak imunitas yang bersifat relatif, dalam arti hak imunitas ini masih dapat dikesampingkan manakala penggunaan hak tersebut "dengan sengaja" dilakukan untuk menghina atau menjatuhkan nama baik dan martabat orang lain, yang tergolong hak imunitas kualifikasi, misalnya; siaran pers tentang isi rapat atau sidang Dewan Perwakilan Rakyat atau sidang pengadilan ataupun laporan pejabat yang berwenang tentang isi rapat Dewan Perwakilan Rakyat atau sidang pengadilan tersebut". ${ }^{18}$

\section{METODE PENELITIAN}

Berdasarkan permasalahan yang menjadi objek penelitian ini, maka tipe penelitian yang digunakan adalah penelitian yuridis normatif, yakni penelitian yang difokuskan untuk mengkaji penerapan kaidahkaidah atau norma-norma dalam hukum positif. Penelitian ini menggunakan "pendekatan konseptual, pendekatan perundang-undangan, dan pendekatan sejarah". ${ }^{19}$ Bahan-bahan hukum yang telah diperoleh, diinventarisasi dan diidentifikasi untuk digunakan sebagai bahan dalam menganalisis pokok permasalahan dalam penelitian ini. Identifikasi bahan hukum baik primer, sekunder, maupun tertier dilakukan secara kritis, logis, dan sistematis, dikumpulkan berdasarkan sistem kartu (card system), "yang memuat sumber yang tepat dari mana catatan itu diambil, informasi atau pendapat yang digunakan, pokok masalah serta kartu yang digunakan adalah kartu kutipan, kartu ulasan, kartu ikhtisar" ${ }^{20}$ hal ini dilakukan untuk mempermudah proses pengolahan data hukum tersebut, dengan demikian bahan hukum akan disusun dan digolongkan menurut bentuk, jenis dan tingkatnya. Adapun bahan hukum yang digunakan dalam penelitian ini adalah:

a. Bahan hukum primer terdiri dari peraturan perundang-undangan yang berhubungan dengan masalah yang dibahas seperti:

UUD 1945, Undang-Undang, Peraturan Pemerintah, Peraturan Daerah, Yurisprudensi dan lain-lain.

b. Bahan hukum sekunder yaitu bahan hukum yang dapat memberikan penjelasan mengenai bahan hukum primer, seperti:

rancangan undang-undang, hasil-hasil penelitian, hasil karya dari kalangan hukum baik berbentuk buku, jurnal hukum, makalah dan lain-lain.

c. Bahan hukum tertier yakni bahan hukum yang dapat memberikan petunjuk maupun penjelasan terhadap bahan hukum primer dan sekunder. Contohnya: kamus, ensiklopedia, indeks komulatif,dan lain-lain

Kemudian dianalisa dengan cara:

1) Menginterpretasikan semua peraturan perundang-undangan sesuai masalah yang dibahas.

2) Menilai bahan-bahan hukum yang berhubungan dengan masalah yang diteliti.

3) Mengevaluasi peraturan perundang-undangan dan bahan-bahan hukum yang berhubungan dengan masalah yang dibahas.

\footnotetext{
${ }^{16}$ Bagir Manan, Op.Cit., hal. 45.

${ }^{17}$ H.A.S. Natabaya, Op.Cit., hal. 60.

${ }^{18}$ Munir Fuady, Konsep Negara Demokrasi, Bandung, Refika Aditama, 2010, hal. 264

${ }^{19}$ Bahder Johan Nasution, Metode Penelitian Ilmu Hukum, Mandar Maju, Bandung, 2008, hal. 92.

${ }^{20}$ Ibid., hal. 106.
} 


\section{HASIL DAN PEMBAHASAN}

Secara umum terdapat dua model sistem perwakilan yang berkembang dalam praktek bernegara, yaitu sistem satu majelis (kamar) dan sistem dua majelis (kamar). Sistem satu kamar biasa juga disebut sebagai unicameral legislature dan sistem dua kamar disebut juga bicameral legislature. ${ }^{21}$

Konsekuensi dari transformasi kewenangan dari DPR, DPD ke MPR memerlukan perubahan terhadap UUD 1945. ${ }^{22}$ Hal tersebut senada dengan yang dikemukakan oleh Usep Ranawidjaja, yang mengatakan bahwa sistem demokrasi dalam negara harus dilembagakan melalui kaidah hukum, yang meliputi : $:^{23}$

1. Jaminan mengenai hak asasi dan kebebasan dasar manusia merupakan syarat berfungsinya kedaulatan rakyat;

2. Penentuan dan pembatasan wewenang pejabat negara;

3. Sistem pembagian tugas antar lembaga penting yang bersifat saling membatasi dan mengimbangi (checks and balances system);

4. Lembaga perwakilan sebagai penjelmaan kedaulatan rakyat dengan tugas perundang-undangan dan mengendalikan badan eksekutif;

5. Pemilihan umum yang bebas dan rahasia;

6. Sistem kepartaian yang menjamin kemerdekaan politik rakyat (sistem multi atau dua partai);

7. Perlindungan dan jaminan bagi kelangsungan oposisi merdeka sebagai potensi alternatif pelaksanaan kedaulatan rakyat;

8. Desentralisasi teritorial kekuasaan negara untuk memperluas partisipasi rakyat dalam mengelola negara; dan

9. Lembaga peradilan yang bebas dari kekuasaan badan eksekutif.

Hak yang dimiliki anggota DPRD sebagaimana termuat dalam Undang-Undang Nomor 23 Tahun

2014 tentang Pemerintahan Daerah, anggota DPRD mempunyai hak :

a. Mengajukan rancangan peraturan daerah;

b. Mengajukan pertanyaan;

c. Menyampaikan usul dan pendapat;

d. Memilih dan dipilih;

e. Membela diri;

f. Imunitas;

g. Mengikuti orientasi dan pendalaman tugas;

h. Protokoler;

i. Keuangan dan administratif.

Setelah adanya reposisi dan refungsionalisasi DPRD, seharusnya DPRD dapat memainkan peranan yang cukup besar dalam pembentukan peraturan daerah, peranan tersebut diwujudkan dalam pengimplementasian dari berbagai tugas, hak dan wewenang yang dimiliki DPRD, salah satunya adalah hak mengajukan Raperda, namun dalam prakteknya hingga saat ini, penggunaan hak mengajukan Raperda tersebut masih minim. ${ }^{24}$

Bertolak dari pendapat CF. Strong tersebut, kedudukan DPRD dalam bingkai Negara Kesatuan Republik Indonesia tidak berdiri sendiri menjadi lembaga legislatif layaknya badan legislatif pusat, dalam hal ini, menempatkan DPRD sebagai bagian dari pemerintahan daerah atau sebagai unsur penyelenggara

\footnotetext{
${ }^{21}$ Susi Dwi Harijanti, Reformasi Sistem Perwakilan Indonesia, Jurnal Konstitusi PSKN FH-Universitas Padjadjaran, Vol.1 No.1 Nov 2009, Mahkamah Konstitusi Republik Indonesia, hal.15

${ }^{22}$ Ibid, hal. 21

${ }^{23}$ Eddy Purnama, Negara Kedaulatan Rakyat, Analisis Terhadap Sistem Pemerintahan

Indonesia dan Perbandingannya Dengan Negara-Negara Lain, Cetakan Kesatu, Nusamedia Bandung dan Imagine Press Malang, 2007, hal. 49

${ }^{24}$ Herma Yanti, “Peranan DPRD Kab.Batanghari dalam Pelaksanaan Hak Mengajukan Rancangan Peraturan Daerah setelah adanya Reposisi dan Refungsional DPRD”, Jurnal Ilmiah Universitas Batanghari Jambi Vol.13 No.04 Tahun 2013, LPPM Universitas Batanghari Jambi, hal. 61
} 
pemerintahan daerah merupakan konsekuensi dari bentuk Negara Kesatuan sebagaimana yang dikemukakan oleh CF. Strong. ${ }^{25}$

Peraturan Daerah juga merupakan salah satu sarana dalam rangka penyelenggaraan otonomi daerah. Dengan kata lain peraturan daerah merupakan sarana yuridis untuk melaksanakan kebijakan otonomi daerah dan tugas-tugas pembantuan. ${ }^{26}$

DPRD mempunyai kedudukan sebagai badan legislatif daerah, seperti halnya distruktur pemerintah pusat, DPR memegang kekuasaan membentuk Undang Undang. Kedudukan DPRD sebagai badan legislatif daerah, membawa akibat bahwa DPRD harus lebih banyak melakukan peran yang berkait dengan kewenangan dan kewajiban yang dibebankan oleh Undang-Undang terhadap DPRD, Konsekuensi dari DPRD sebagai badan legislatif daerah, semua produk perundang-undangan daerah harus menggunakan dan bersumber dari DPRD. ${ }^{27}$

Kesulitan lainnya bagi anggota DPRD, terdapat pada hak imunitas. Hak imunitas yang melekat pada DPR ataupun DPRD menimbulkan pro dan kontra, ada yang menganggap bahwa perlakuan berbeda terhadap anggota DPRD dianggap sudah tepat karena pejabat negara berbeda dengan warga negara biasa, ada juga yang beranggapan bahwa hal itu tidak wajar karena setiap warga negara mempunyai kedudukan sama di hadapan hukum, pembedaan tersebut jelas bertabrakan dengan asas equality before the law. ${ }^{28}$

Dalam pelaksanaannya pada tingkat penyidikan pihak kepolisian, hak imunitas DPRD tentunya menjadi bahan pertimbangan untuk melakukan pemanggilan sebelum melakukan pemeriksaan terhadap anggota DPRD, jika pihak kepolisian mengabaikan hak imunitas tersebut maka berarti mengingkari hak imunitas DPRD yang telah diatur dalam peraturan perundang- undangan, dengan kata lain masalah pokok dalam hak imunitas DPRD sebenarnya terkait dengan tata cara pemanggilan anggota DPRD yang diduga melakukan tindak pidana. ${ }^{29}$

Hak imunitas dapat diketahui dalam Undang-Undang Nomor 17 Tahun 2014 Tentang MPR,DPR,DPD dan DPRD:

Pasal 338

(1) Anggota DPRD provinsi mempunyai hak imunitas.

(2) Anggota DPRD provinsi tidak dapat dituntut di depan pengadilan karena pernyataan, pertanyaan, dan/atau pendapat yang dikemukakannya baik secara lisan maupun tertulis di dalam rapat DPRD provinsi ataupun di luar rapat DPRD provinsi yang berkaitan dengan fungsi serta wewenang dan tugas DPRD provinsi.

(3) Anggota DPRD provinsi tidak dapat diganti antar waktu karena pernyataan, pertanyaan, dan/atau pendapat yang dikemukakannya baik di dalam rapat DPRD provinsi maupun di luar rapat DPRD provinsi yang berkaitan dengan fungsi serta wewenang dan tugas DPRD provinsi.

(4) Ketentuan sebagaimana dimaksud pada ayat (1) tidak berlaku dalam hal anggota yang bersangkutan mengumumkan materi yang telah disepakati dalam rapat tertutup untuk dirahasiakan atau hal lain yang dimaksud dalam ketentuan mengenai rahasia negara sesuai dengan ketentuan peraturan perundangundangan.

Hak imunitas menjadi perdebatan mengingat hanya kalangan tertentu saja yang mendapat hak eksklusif ini, selain itu dengan adanya hak imunitas juga menimbulkan perdebatan mengenai supremasi hukum dan kedudukan yang sama di depan hukum. ${ }^{30}$

Menurut Munir Fuady, pada umumnya pengertian fungsi legislatif yang dilindungi berdasarkan konsep hak imunitas ini mencakup hal-hal: (1). Kebebasan berbicara dan berdebat di dalam sidang atau

${ }^{25}$ Jorawati Simarmata, Op.Cit., hal.2

${ }^{26}$ Jimly Assidiqie, Pengantar Ilmu Hukum Tata Negara Jilid II, Konpress, Jakarta, 2005, hal. 175

${ }^{27}$ Adriana Mustafa, "Implementasi antara Legilatif dan Eksekutif dalam Pembentukan Peraturan Daerah yang Partisipatif", Jurnal Al-Qadau Vol.5 No.2 Desember 2018, Jurusan Hukum Acara Peradilan dan Kekeluargaan Fak.Syariah dan Hukum UIN Alauddin Makassar, hal. 296

${ }^{28}$ Jorawati Simarmata, Op.Cit., hal . 2

${ }^{29}$ Ibid, hal. 3

${ }^{30}$ Anugrah A.P, "Penerapan Hak Imunitas yang Dimiliki oleh Anggota DPR RI dan Urgensi Forum Previlegiatum", Diponegoro Law Review Vol.5 No.2 2016, Fakultas Hukum Universitas Diponegoro, hal. 3 
rapat-rapat di parlemen, (2). Pemungutan suara secara bebas di parlemen, (3). Penyediaan laporan-laporan fraksi, komisi atau pribadi anggota parlemen, (4).Partisipasi dalam hearing, rapat, sidang, di parlemen atau dalam tinjauan lapangansecara resmi oleh parlemen atau anggota parlemen, (5). Kebebasan untuk tidak ditangkap dan ditahan, (6). Kebebasan untuk tidak dituduh melakukan tindak pidana penghinaan atau penistaan. ${ }^{31}$

Pada prinsipnya UU Nomor 17 Tahun 2014 mengakui eksistensi hak imunitas DPRD baik DPRD Provinsi maupun DPRD Kabupaten/Kota. Hal tersebut diakomodir dalam Pasal 107 huruf f, Pasal 122 ayat (1), Pasal 160 huruf $f$ dan Pasal 176 ayat (1) UU Nomor 17 Tahun 2014. Namun ketentuan Pasal 409 huruf d UU Nomor 23 Tahun 2014 tentang Pemerintahan Daerah mencabut pengaturan tentang hak imunitas DPRD yang diatur dalam UU Nomor 17 Tahun

2014. Konsekuensinya seluruh materi muatan yang terkait dengan DPRD yang diatur UU Nomor 17 Tahun 2014, dicabut dan tidak berlaku. ${ }^{32}$

Imunitas merupakan tejemahan dari kata "immunity" yang berarti kekebalan. Kekebalan berasal dari kata kebal yang dalam bidang hukum artinya tidak dapat dituntut. ${ }^{33}$ Imunitas Hukum di Indonesia sendiri merupakan sebuah hak yang diberikan negara untuk dimiliki oleh pihak legislatif dan pihak eksekutif dalam konteks menjalankan tugas kenegaraan. ${ }^{34}$ Dalam hal ini, dapat dikemukakan adanya imunitas hukum pada anggota DPR berdasarkan Pasal 20A UUD 1945 sebagai salah satu hak individual yang dimiliki oleh setiap anggota DPR dalam menjalankan tugasnya.

Selama ini, pelaksanaan fungsi legislasi Dewan Perwakilan Rakyat Daerah belum optimal karena terdapatnya hambatan-hambatan, di antaranya adalah kurangnya anggaran dalam pembahasan peraturan daerah. Oleh karena itu, agar fungsi legislasi Dewan Perwakilan Rakyat Daerah dapat optimal, maka diperlukan upaya-upaya agar fungsi tersebut dapat berjalan dengan baik.

Peraturan daerah merupakan perwujudan dari fungsi legislasi yakni merupakan fungsi dari parlemen untuk membentuk produk hukum yang bersifat mengatur, hal ini berkenaan dengan kewenangan untuk menentukan peraturan yang mengikat warga negara dengan norma hukum yang mengikat dan membatasinya. ${ }^{35}$ Dengan kata lain peraturan daerah merupakan sarana yuridis untuk melaksanakan kebijakan otonomi daerah dan tugas-tugas pembantuan. ${ }^{36}$ Pada prakteknya dalam membentuk peraturan perundang-undangan termasuk menyusun dan membentuk peraturan daerah DPRD seringkali mengalami kesulitan dalam memunculkan inisiatif penyusunan Peraturan Daerah yang akan menjadi kebijakan dalam penyelenggaraan pemerintahan dan pembangunan. ${ }^{37}$

Rumusan Pasal 20 A ayat (3) UUD RI 1945 "yang dinyatakan bahwa selain hak yang diatur dalam pasal-pasal lain UUD ini, DPR mempunyai hak menghajukan pertanyaan, menyampaikan usul dan pendapat, serta hak imunitas, dalam pelaksanaannya pada tingkat penyidikan pihak kepolisian, hak imunitas DPRD tentunya menjadi bahan pertimbangan untuk melakukan pemanggilan sebelum melakukan pemeriksaan terhadap anggota DPRD. Jika pihak kepolisian mengabaikan hak imunitas tersebut maka berarti mengingkari hak imunitas DPRD yang telah diatur dalam peraturan perundang- undangan. Dengan kata lain masalah pokok dalam hak imunitas DPRD sebenarnya terkait dengan tata cara pemanggilan anggota DPRD yang diduga melakukan tindak pidana. ${ }^{38}$

Dalam UU Nomor 23 Tahun 2014 tentang Pemerintahan Daerah, Hak Imunitas anggota DPRD diakomodir secara jelas sebagaimana pengaturan hak imunitas anggota DPRD di UU Nomor 17 Tahun 2014. Dalam konteks UU Nomor 23 Tahun 2014, khususnya Pasal 122 UU Nomor 23 Tahun 2014 bagi

\footnotetext{
${ }^{31}$ Supriyadi A Arief, "Dekonstruksi Hak Imunitas Anggota DPR dalam Perspektif Equality Before The Law, Jurnal Jambura Law Review Vol.01 Issue 01 Januari 2019, Fakultas Hukum Universitas Negeri Gorontalo, hal. 29

${ }^{32}$ Jorawati Simarmata, Op.Cit., hal.6

${ }^{33}$ W.J.S. Poerwadarminta, Kamus Umum Bahasa Indonesia, Jakarta: PT. Balai Pustaka, 1976 hal. 455.

${ }^{34}$ Jorawati Simarmata, Op.Cit., hal.5

${ }^{35}$ Soenobo Wirjosoegito, Proses dan Perencanaan Peraturan Perundang-undangan, Jakarta, Ghalia Indonesia, 2009, hal.128

${ }^{36}$ Jimly Assidiqie, Pengantar Ilmu HTN jilid II, Konpress, Jakarta, 2005, hal. 175

${ }^{37}$ Mutiq Hasan Nasir, Op.Cit., hal .3

${ }^{38}$ Jorawati Simarmata, Op.Cit., hal.3
} 
anggota DPRD Provinsi dan Pasal 176 UU Nomor 23 Tahun 2014 bagi anggota DPRD Kabupaten/Kota, hak imunitas anggota DPRD dimaknai sebagai berikut ${ }^{39}$ :

1. Anggota DPRD tidak dapat dituntut di depan pengadilan karena pernyataan, pertanyaan, dan/atau pendapat yang dikemukakannya baik secara lisan maupun tertulis di dalam rapat DPRD ataupun di luar rapat DPRD yang berkaitan dengan fungsi serta wewenang dan tugas DPRD.

2. Anggota DPRD tidak dapat dituntut di depan pengadilan karena sikap, tindakan, kegiatan di dalam rapat DPRD ataupun di luar rapat DPRD yang semata-mata karena hak dan kewenangan konstitusional DPRD dan/atau anggota DPRD.

3. Anggota DPRD tidak dapat diganti antarwaktu karena pernyataan, pertanyaan, dan/atau pendapat yang dikemukakannya baik di dalam rapat DPRD maupun di luar rapat DPRD yang berkaitan dengan fungsi serta wewenang dan tugas DPRD.

\section{KESIMPULAN}

Pelaksanaan hak mengajukan rancangan peraturan daerah mengalami perkembangan yang positif dari masa ke masa, dan pelaksanaan hak imunitas pun mengalami perkembangan yang positif sehingga anggota DPRD lebih kritis atas kebijakan pemerintah daerah sehingga diharapkan daerah menjadi lebih baik.

\section{DAFTAR PUSTAKA}

\section{Buku}

Bagir Manan. 2002. Menyongsong Fajar Otonomi Daerah. Pusat Studi Hukum Fakultas Hukum UII. Yogyakarta.

Bagir Manan. 2005. DPR, DPD, dan MPR dalam UUD 1945 BARU. UII Press, Yogyakarta.

Bahder Johan Nasution. 2008. Metode Penelitian Ilmu Hukum. Mandar Maju, Bandung.

B.N.Marbun. 2005. "Perwakilan Politik Lokal dan Eksistensi DPRD dalam Konteks Otonomi Daerah" dalam Pasang Surut Otonomi Daerah, Cet. 1., Editor Anhar Gonggong. Institute for Local Development. Jakarta.

Deddy Supriady Bratakusumah dan Dadang Solihin. 2002. Otonomi Penyelenggaraan Pemerintahan Daerah. Gramedia Pustaka Utama.

Eddy Purnama. 2007. Negara Kedaulatan Rakyat, Analisis Terhadap Sistem Pemerintahan Indonesia dan Perbandingannya Dengan Negara-Negara Lain. Cetakan Kesatu. Nusamedia Bandung dan Imagine Press Malang.

H.A.S. Natabaya. 2004. Menjaga Denyut Konstitusi, Refleksi Satu Tahun Mahkamah Konstitusi. Konstitusi Press, Jakarta.

Jimly Assidiqie. 2005. Pengantar Ilmu HTN jilid II. Konpress. Jakarta.

Jimly Assidiqie. 2005. Pengantar Ilmu Hukum Tata Negara Jilid II. Konpress, Jakarta.

Jimly Asshiddiqie. 2009. Pengantar Ilmu Jukum Tata Negara. Rajawali Pers, Jakarta.

La Ode Husen. 2005. Hubungan Fungsi Pengawasan DPR dengan BPK dalam Sistem Ketatanegaraan Indonesia. CV. Utomo, Bandung.

Munir Fuady. 2010. Konsep Negara Demokrasi, Refika Aditama, Bandung.

Soenobo Wirjosoegito. 2009. Proses dan Perencanaan Peraturan Perundang-undangan. Jakarta. Ghalia Indonesia.

Sukamto Satoto. 2004. Pengaturan Eksistensi \& Fungsi Badan Kepegawaian Negara. UII Press, Yogyakarta.

W.J.S. Poerwadarminta. 1976. Kamus Umum Bahasa Indonesia. Jakarta. PT. Balai Pustaka.

\section{Jurnal/Tesis}

Adriana Mustafa, "Implementasi antara Legilatif dan Eksekutif dalam Pembentukan Peraturan Daerah yang Partisipatif", Jurnal Al-Qadau Vol.5 No.2 Desember 2018, Jurusan Hukum Acara Peradilan dan Kekeluargaan Fak.Syariah dan Hukum UIN Alauddin Makassar. 
Anugrah A.P, "Penerapan Hak Imunitas yang Dimiliki oleh Anggota DPR RI dan Urgensi Forum Previlegiatum”, Diponegoro Law Review Vol.5 No.2 2016, Fakultas Hukum Universitas Diponegoro.

Herma Yanti, "Peranan DPRD Kab.Batanghari dalam Pelaksanaan Hak Mengajukan Rancangan Peraturan Daerah setelah adanya Reposisi dan Refungsional DPRD”, Jurnal Ilmiah Universitas Batanghari Jambi Vol.13 No.04 Tahun 2013, LPPM Universitas Batanghari Jambi.

Jorawati Simarmata, "Menafsirkan Hak Imunitas Anggota DPRD", Jurnal Legislasi Indoneisia Vol.15 No.01 Maret 2018, Dirjen Peraturan Perundang-undangan Kemenkumham RI.

Mutiq H.N, "Pelaksanaan Fungsi Legislasi DPRD dalam Pembentukan Peraturan Daerah di Kabupaten Nunukan, Tesis, Magister Administrasi Publik Universitas Terbuka, 2018.

Supriyadi A Arief, “Dekonstruksi Hak Imunitas Anggota DPR dalam Perspektif Equality Before The Law, Jurnal Jambura Law Review Vol.01 Issue 01 Januari 2019, Fakultas Hukum Universitas Negeri Gorontalo.

Susi Dwi Harijanti, Reformasi Sistem Perwakilan Indonesia, Jurnal Konstitusi PSKN FH-Universitas Padjadjaran, Vol.1 No.1 Nov 2009, Mahkamah Konstitusi Republik Indonesia.

\section{Peraturan Perundang-undangan}

Republik Indonesia. Undang-Undang Dasar Republik Indonesia. Undang-Undang Dasar Tahun 1945.

Republik Indonesia. Undang-Undang Tentang Majelis Permusyawaratan Rakyat, Dewan Perwakilan Rakyat, Dewan Perwakilan Daerah dan Dewan Perwakilan Rakyat Daerah. Undang-Undang Nomor 17 Tahun 2014.

Republik Indonesia. Undang-Undang Tentang Pemerintahan Daerah. Undang-Undang Nomor 23 Tahun 2014. 